\title{
CHOSEN ASPECTS OF TRADE EXCHANGE BETWEEN UKRAINE AND THE EUROPEAN UNION
}

\section{Patrycja Zwiech}

\begin{abstract}
Cooperation between Ukraine and European Union is of major importance in the system international relations on European continent. After the creation of independent Ukrainian country and shaping the statutory framework for formulating Common Foreign and Security Policy for the European Union and after signing the Maastricht Treaty, main principles underlying the functioning of these entities on an international arena have been formulated.

Due to its geopolitical importance, Ukraine can play a crucial role in the formulation_of Common Foreign and Security Policy (CFSP) for the European Union, as long as it offers European Union with a new possibility of developing a new political strategy. What is more, the importance of Ukraine to the EU also stems from its strategic location, i.e. it is a transit track for energy resources (gas and oil), running from Russia. Thus, supplying a greater part of EU with energy resources depends on political and economic stability of Ukraine.

Furthermore, it should be noticed that European Union is one of major trading partners that Ukraine has. It is beyond any doubt that EU is definitely the biggest investor in Ukraine.

Trade exchange between Ukraine and European Union increases every year. In the period 2000 - 2007 import of goods from the EU to Ukraine increased over fourfold (from 5.5 bn Euro to 22.4 bn Euro), and export from Ukraine to EU-27 Member States increased from 4.8 bn to $12.4 \mathrm{bn}$.

The present article is aimed at presenting the figures of trade exchange between Ukraine and EU Member States as well as major trading partners that Ukraine has among EU Member Stated in comparison with legal regulations established between Ukraine and the European Union (particularly framework and sectoral in nature).
\end{abstract}

Keywords: trade exchange, Ukraine, European Union 